\title{
PRIORITY MODALITY IN POLITICAL WRITING - THE CASE OF THE EUROPEAN COMMISSION'S SERBIA 2019 REPORT
}

This study aims to analyse modal phrases in the European Commission's Serbia 2019 report and to draw conclusions about modality in political writing in general. 560 phrases with modal meaning were identified in the report. The most frequent are modal verbs need and should and adverbs still and yet. The verb following the modal form is usually in passive. Almost all the modals belong to the category of priority modality, most commonly deontic. All priority modals analysed are directives, specifically obligatives. All priority modal verbs were used subjectively. The study concludes that political writing in general is of modal nature.

Keywords: political writing, modality, priority modality, obligatives, subjectivity.

\section{Introduction}

"In our time it is broadly true that political writing is bad writing." This is a quote from George Orwell's notorious essay Language and Politics (1946) that reflects how the general public feel about the language used in politics. Orwell (1946) also states that „Political language ... is designed to make lies sound truthful and murder respectable, and to give an appearance of solidity to pure wind." It is the general opinion that politicians are deliberately vague in order to hide their true intentions. However, we must ask ourselves whether this claim is always accurate.

*_djole.dim@hotmail.com 
The main aim of a politician communicating with the public is to attract and retain voters. In order to do so, they must present their ideas clearly and persuasively. They cannot afford to be vague. The voters demand to know where politicians stand on certain issues, and politicians need to comply in order to get their attention. They get limited media space and they need to make the most of it.

Political discourse is in most cases conducted orally. The most prominent example are political speeches where a politician talks to their supporters in order to direct their energy to an action. Similar are panel discussions, where a group of likeminded politicians talk about an issue approaching it from multiple sides. On the other hand, there are debates, where multiple politicians of opposing views present their side of the argument and attempt to disprove the other side. Another example of oral political discourse are interviews, where a journalist asks a politician a series of questions and reports their answers. Interviews reach the public in written or video form, but are usually conducted orally.

When it comes to political writing, there are also several varieties. Firstly, there are political pamphlets in which a political party tries to persuade the readers to vote for them or to take their side with a certain issue. Also, political parties and individual politicians regularly publish statements to inform the public of their views on current events. There are also cases when a politician publishes a text in a newspaper, usually criticizing the actions of the government. One type of political writing that is becoming increasingly relevant are social media publications, which are similar to statements, but are done in a much more personalized way. Finally, there are various kinds of reports that politicians write to their respective institutions. Although these reports usually use formal language, they are mostly not meant only for the institution, but are made available to the general public, who are the actual target audience. One such a report will be the object of analysis of the present study.

Serbia is a candidate country for membership in the European Union. In order to become a Member State, Serbia needs to work on improvements in its institutions, practices, economy, and many 
other areas to reach the standards of the European Union. The European Commission assists Serbia in its reforms, but it also assesses their progress. The work that Serbia needs to do has been broken down into 35 negotiating chapters, so that each are can be addressed individually. So far, 16 chapters have been opened for negotiations and two have been provisionally closed (European Commission 2019: 3). Every March, the European Commission publishes a report in which they asses the progress of the reforms in the previous year. The reports not only list what improvements have been made, but also recommend what should be done in the following period. The publishing of the European Commission's report is a major event in Serbian political life, as it is viewed as an objective analysis of the government's work, and because it reflects the disposition of the leaders of the European Union towards the Serbian government.

Up to 2019 these reports were overall positive with recommendations for further work. However, the 2019 report is considerably different. It puts much more emphasis on the problems in Serbia rather than the successful reforms. One of its main points is the existence of weekly anti-government protests and the opposition's parliamentary boycott. It also highlights the need for the reform of the public administration and the judicial system. Additionally, it criticizes the lack of progress in the fight against corruption and organized crime. On the other hand, it mostly commends the economic reforms. Finally, it urges for more efforts for the normalization of relations with Kosovo* (European Commission 2019: 3-5).

\section{Theoretical Background}

Modal propositions are those whose truth value is not asserted by the speaker (Palmer 1986: 1-4). "Modality is concerned with the status of the proposition that describes the event" (Palmer 1986: 1). Palmer contrasts propositional and event modality (Palmer 1986: 7-8). He states that "epistemic modality and evidential modality are concerned with the speaker's attitude to the truth- 
value or factual status of the proposition (Propositional modality)", whereas "deontic and dynamic modality refer to events that are not actualized, events that have not taken place but are merely potential (Event modality)" (Palmer 1986: 8). Propositional modality is further divided into epistemic and evidential: "The essential difference between these two types is ... that with epistemic modality speakers express their judgments about the factual status of the proposition, whereas with evidential modality they indicate the evidence they have for its factual status" (Palmer 1986: 8). On the other hand, event modality is divided into deontic and dynamic: "deontic modality relates to obligation or permission, emanating from an external source, whereas dynamic modality relates to ability or willingness, which comes from the individual concerned" (Palmer 1986: 9-10).

With regard to meaning, Palmer (1986) divides deontic modal forms into directives (obligatives and permissives) and commissives. Directives are the modal forms the speaker uses to direct the addressee's actions. Obligatives are directives where the speaker gives a command to the addressee. Permissives are directives where the speaker gives his permission for an action that the addressee is able to take. Finally, commissives are speech acts in which the speaker personally guarantees that a certain action will take place. "Here the speaker commits himself to ensuring the event takes place" (Palmer 1986: 73).

Verstraete (2001) summarizes different authors' theories on modal subjectivity and objectivity. He defines subjective uses of deontic modals as those that "clearly serve to encode the speaker's commitment to the necessity/permissibility of an action" (2001: 1525 ) and objective uses as those that "merely predicates the existence of some necessity without actually committing the speaker to it" (Verstraete 2001: 1525). He also proposes three tests to determine whether a modal verb is used subjectively or objectively: conditionality, interrogation, and tense shift.

Conditionality is used as a test by using the sentence containing a modal verb as the protasis of a conditional sentence. In this context subjective modals get an echoic interpretation, whereas 
objective modals' meaning does not change. "[T]he performative modal in a conditional protasis is no longer pet-formative in the sense of expressing a position of the current speaker, but comes to function as a propositionalized resumption of a context where the modal did have a performative function, usually expressing another speaker's position“ (Verstraete 2001: 1520).

When subjective modals are placed into an interrogative sentence, the interlocutors' roles become reversed. The addressee becomes the person holding authority. This does not occur with objective modals. "[S]ubjective modals are oriented towards the interlocutor under the influence of interrogation, whereas objective modals remain unaffected" (Verstraete 2001: 1521).

In Portner (2009), modality is divided into three distinct categories: epistemic, priority and dynamic. "Epistemic modals are those pertaining to the speaker's knowledge" (Portner 2009: 135). Those are the modals connected to speculation and deduction. "Priority modals have to do with reasons for preferring one situation over another " (Portner 2009: 184). They are the ones the speaker uses to direct someone's behaviour. "The idea behind the term 'priority' is that such things as rules, desires, and goals all serve to identify some possibility as better than, or as having higher priority than, others" (Portner 2009: 135). Portner subdivides priority modals to deontic, bouletic and teleological. It is precisely because of this sub-division that Portner's model is the one used in the present study. Since priority modals are the largest group in the report, it would be beneficial for the study to further group them. Finally, dynamic modals are the ones "which have to do with the ways in which circumstances affect the actions available to a volitional individual" or "produce existential or universal quantification over individuals" (Portner 2009: 135). They are subdivided into volitional and qualificational modals.

Portner (2009) divides priority modals into deontic, bouletic and teleological. "[D]eontic modality has to do with obligations, right and wrong, and other such normative notions" (Portner 2009: 185). This includes giving commands and permission. "Bouletic modals have to do with someone's desires" (Portner 2009: 185). "[T] 
eleological (or goal-oriented) ones [have to do] with somebody's goals" (Portner 2009: 185). These include telling someone what they ought to do in order to achieve their goals.

There are numerous studies dealing with modality in political discourse, such as Boicu (2007). In this paper, the researcher analyses the use of both epistemic and deontic modal verbs in the speeches of Ashley Mote, a British nationalist politician. By combining literature on modality and pragmatics, the paper comes to the conclusion that the speaker uses modal verbs to enhance the illocutionary force of Face Threatening Acts (FTA). In some cases, modals aggravate FTAs using must or can't, but in most cases modal verbs are used to mitigate the force of FTA, the most common being should and need to (Boicu 2007).

Another such paper is Milkovich and Sitarica (2017). Here the researchers analyse epistemic modality in speeches by the former UK Prime Minister Tony Blair and the former US President George W. Bush and their associates on the Iraq War and Iran sanctions. The study concludes that the politicians' use epistemic modals represents a face-saving strategy, by distancing them from their claims. The verbs most commonly used as hedging devices are may, might, can and could (Milkovich and Sitarica 2017).

Most studies examining modality in political discourse focus on speeches. What makes the present study different is that its subject is written language.

\section{Aim and methodology}

The aim of the present study is to identify and analyse modal forms used in the European Commission's Serbia 2019 Report (Report 2019 in the remainder of the text), to categorize them according to type of modality and meaning, and to investigate whether they are used subjectively or objectively, in order to provide a description of modality in political writing in general. All examples of sentences containing modal forms are extracted from the report and analysed in terms of which part of speech they are, whether they are connected to an active or a passive verb, type of modality, 
meaning, and subjectivity. The study uses both quantitative results and qualitative descriptions in order to produce the best possible account of modality in political writing.

Apart from modal verbs, the study takes into account all forms with modal meaning, including verbs, nouns, adverbs and adjectives. Focus only on modal verbs would severely limit the study and would not identify all modal forms used in political writing, which is one of the aims of the study. Instead, the focus of this exploration shall be modal phrases: all phrases that signal that the proposition is placed into the domain of irealis. The use of passive is typical in political language and is very often significant. The study hypothesizes various different parts of speech used as modal forms with frequent use of passive.

Even though modality is traditionally divided into epistemic, deontic, and dynamic, this study opts for the division to epistemic, priority, and dynamic, as outlined in Portner (2009). The reason for this is that the initial hypothesis that the largest number of modals in the report would fall into the priority category, and that the subdivision between deontic, bouletic, and teleological modals within the category of priority modals would benefit the study. Further analysis only includes priority modals as the most relevant.

The analysis of modal meaning is conducted according to Palmer's (1986) terms of directives (obligatives and permissives) and comissives. The purpose of this analysis is to see what modal forms are used in these kinds of documents. The hypothesis of this study is that obligatives are the most common in political writing.

Finally, the modal forms are analysed for subjectivity and objectivity, as described in Verstraete (2001). This entails testing the modal forms by interrogation, conditional, and change of tense. The study hypothesizes a mix of subjective and objective modality.

Finally, the findings of this study will be put into the wider context in order to extrapolate a description of modality in political writing in general. 


\section{Findings}

\subsection{Identified modal phrases}

\subsubsection{Modal verbs}

Upon examining the entire report, 560 sentences containing phrases with modal meaning were identified. They were then grouped by the part of speech.

Predictably, the most numerous group are sentences with modal verbs. By far, the most frequent modal verb in the report is need to. Here is one example:

(1) Serbia needs to fully address all recommendations on the elections, identified by international observers, as a matter of priority. (4)

These sentences mostly take the form Serbia needs to... or Institution $X$ needs to.... However, more often than not, the verb following need to is in passive, for example:

(2) Consistent and efficient implementation of legislation and policies needs to be ensured. (24)

The prolific use of passive could simply be there to avoid repetition of Serbia needs to, but it could also represent a facesaving act, where what needs to be done is pointed out without pointing fingers at who is responsible for doing it. In total, there are 216 sentences that contain need to, 92 of which are used with an active verb, and 124 with a passive verb.

Another modal verb very common in the report is should, such as in:

(3) In the context of being granted the seat of the Transport Community Treaty Secretariat, Serbia should now provide further support to ensure the conditions are in place for it to take up operations swiftly. (53)

2 All examples are from the European Commision's (2019) Serbia 2019 Report, followed by their page number given in brackets. 
In the context of this report, the verbs need to and should are used synonymously, in order to give recommendations. At the beginning of every chapter of the report, there is a recurring pattern that starts with Serbia should in particular... For example:

(4) In the coming year, Serbia should in particular:

-start recruiting senior civil servants effectively through a merit-based procedure and reduce the excessive number of acting positions;

-issue practical guidance to line institutions on strategic planning, monitoring and reporting and ensure a strong quality control role for the Public Policy Secretariat to allow for the effective implementation of the new Law on the planning system;

-develop a single mechanism for prioritising all investments regardless of the source of financing and ensure integration of capital investment planning and project appraisal in the budget process. (10)

Unlike need to, should is more often used with an active verb, but there are a lot of examples where should is followed by a verb in passive, such as:

(5) These reforms should be undertaken in an inclusive and transparent manner, and as a matter of priority ahead of the next elections. (7)

It is possible that the verb should is perceived as having less illocutionary force than need to, and therefore is less face threatening, so it does not require passive to mask the subject of the sentence. Throughout the report, should is used 122 times, 74 times with an active verb and 48 times with a passive verb.

There are surprisingly few instances of the verbs must and have to. Must was used only 8 times, 5 times with an active, and 3 times with a passive verb. Here is one example:

(6) The energy agreement between Serbia and Kosovo must be implemented without further delay in order to avoid this long standing dispute from having further consequences for energy 
stability and security in Serbia, Kosovo and countries across Europe. (55)

An interesting fact is that must is almost exclusively used in the context of relations with Kosovo and the obligations of EU Member States. It is probable that must is perceived as extremely face threatening, and is, thus, avoided, except when the writer wants to particularly stress the obligation. The sentences about Member States are the exception, because the object of the report, Serbia, is not one of them.

Similarly, have to is used only 4 times in the report, and only once with a passive verb, for example:

(7) Confiscation of criminal assets still has to become a strategic priority in the fight against organised crime, terrorism and high-level corruption in Serbia. (34)

The only other modal verbs used in the report are can and could. Can is used 6 times, always with the following verb in active, one of which is:

(8) Statements by high-ranking state officials on the daily and investigative work of journalists are preventing the creation of an environment where freedom of expression can be exercised without hindrance. (27)

Could is used just 4 times, 3 times with an active, and once with a passive verb, for example:

(9) The clause stipulated that the gas supplied under the agreement was intended for use in the Serbian market only, thereby restricting the territory to which the Serbian buyer could sell the gas. (73)

\subsubsection{Other verbs and verb phrases}

The most common non-modal verb used in the report with a modal meaning is remain. This verb is used to direct attention to an issue that had been mentioned in previous reports and has not been resolved yet, such as in: 
(10) However, concerns related to the effective implementation of functional unbundling related to independent decisionmaking remain. (74)

One specific sentence with this verb that is repeated several times in the report is:

(11) Last year's recommendations were not implemented and remain valid. (75)

In total the verb remain was used 36 times in the report, only 4 times with the following verb in passive.

Another frequent verb in the report is require. It is used 7 times, always followed by an active verb. For example:

(12) Continuous training activities, which also require coordination efforts in order to avoid overlapping, are still highly dependent on different donors. (17)

Other verb phrases with modal meaning included in the report are: leads to uncertainty, provides a good opportunity to, would benefit from, continue to be and is not contributing to.

Finally, there are two instances of the verb seem, and one of the verb appear. Here is an example:

(13) Granting of State aid seems to favour market incumbents and large investors. (46)

\subsubsection{Adverbs}

Throughout the report adverbs are often used to give the sentence a modal meaning. The most common adverb used in this sense is still. Similarly to the verb remain, it points to an issue that had been mentioned in previous reports and hasn't been resolved yet, such as in:

(14) A national strategy and action plan to contribute to an enabling environment for civil society have still not been adopted. (8) 
This sentence is modal because it represents a directive for adopting a national strategy and action plan. Still is used 70 times in the report, only 6 times with a passive verb. Also, still is often used in the combination with need to, like in (15):

(15) Law enforcement and judicial authorities still need to establish a credible track record of operationally independent prosecutions and of finalised high-level corruption cases. (20)

Another frequent adverb used in a similar way is yet. For example:

(16) Serbia has yet to establish a convincing track record of effective investigations, prosecutions and final convictions in organised crime cases, including financial investigations leading to a track record of freezing and confiscating criminal assets. (32)

The main difference between these two adverbs is that yet is much more often followed by a passive verb, such as in:

(17) A coordinated monitoring and reporting system of the public administration reform strategy and public financial management reform programme is yet to be established. (4)

There is a recurring pattern in a report with sentences in the form of The X Law has yet to be adopted, for example:

(18) A law for the prevention of ill-treatment and abuse in social institutions has yet to be adopted. (25)

Yet is used 65 times in total, 16 times with an active and 49 times with a passive verb.

Other adverbs used with a modal meaning in the report are only, not sufficiently and potentially.

\subsubsection{Adjectives and participles}

There are a lot of different adjectives and participles used with a modal meaning in the report. The most frequent of them is needed, used 39 times, one of which is: 
(19) Further efforts are needed to promote EU values in

Serbian public debate and in education, including readiness for reconciliation. (9)

These sentences often take the form Further efforts are needed to... or Changes in $X$ are needed to... This adjective is often combined with the adverb still such as in:

(20) Constitutional changes are still needed in some areas to address issues relevant to the accession negotiations. (9)

Another adjective that is repeated throughout the report is pending. For example:

(21) Further improvement of internal capacity and organisation of the Judicial Academy is pending. (17)

Just like needed, it is often combined with still, such as in:

(22) The adoption of a strategic framework on disability is still pending. (29)

In total, pending is used 12 times in the report.

One more adjective with modal meaning that is repeated multiple times, 5 in total, is crucial, such as in:

(23) In the current polarised environment, it is crucial that cross-party debate and meaningful participation in the parliament are restored as a matter of priority. (8)

There are several other adjectives and participles used with a modal meaning, but they are only used once or twice throughout the report. They include: urgent, important, encouraged, responsible, insufficient, critical, required, recommended, necessary, instrumental. It is interesting to note that all these adjectives and participles are almost exclusively used with an active verb.

\subsubsection{Nouns and noun phrases}

There are some cases in the report where nouns and noun phrases are the ones who carry modal meaning. The most common of these nouns in the report is need. It is found in constructions 
There is a need to/for... such as in:

(24) As regards the political criteria, there is an urgent need to create more space for genuine cross-party debate, in order to forge a broad pro-European consensus which is vital for the country's progress on its EU path. (4)

This construction is used 9 times in the report. Other occurring nouns and noun phrases with modal meaning are lack, key and an issue to be followed.

\subsubsection{Conjunctions and conditionals}

There are two cases where conjunctions, instead of and due to, carry modal meaning:

(25) In addition, the available fiscal space has been used mostly for current spending and non-productive capital expenditure, instead of for more growth-friendly spending on infrastructure and basic public services. (51)

(26) Capacity of the judiciary to handle IPR cases is still low, due to the low level of specialisation of judges in this field. (62)

There are also 2 conditional sentences in the report.

\subsubsection{Modification}

There are several phrases used to modify modal expression in order to increase their force. The most common one is as a matter of priority/urgency, such as in:

(27) Serbia needs to address, as a matter of priority, issues of non-compliance with the SAA, regarding in particular state aid control, fiscal discrimination on imported spirits, and restriction to competition in the card-based payment system. (6)

Another one used consistently throughout the report to give just a little more strength to the modal is in particular. For example: 
(28) In the coming year, Serbia should, in particular:

$\rightarrow$ take further steps to boost the administrative capacity of the coordination group and the various institutions involved in the own resources system;

$\rightarrow$ develop the organisational and procedural links between these institutions;

$\rightarrow$ step up preparations to meet the specific administrative conditions for own resources, as laid down in the own resources regulations. (95-96)

Table 1. Number of identified modal phrases with active/passive

\begin{tabular}{|l|c|c|c|}
\hline & $\begin{array}{c}\text { With an active } \\
\text { verb }\end{array}$ & $\begin{array}{c}\text { With a passive } \\
\text { verb }\end{array}$ & In total \\
\hline need to & 92 & 124 & 216 \\
\hline should & 74 & 48 & 122 \\
\hline must & 5 & 3 & 8 \\
\hline have to & 3 & 1 & 4 \\
\hline can & 6 & 0 & 6 \\
\hline could & 1 & 1 & 2 \\
\hline modal verbs total & 181 & 177 & 361 \\
\hline remain & 29 & 4 & 33 \\
\hline require & 7 & 0 & 7 \\
\hline would benefit from & 2 & 0 & 2 \\
\hline leads to uncertainty & 1 & 0 & 1 \\
\hline provides good & 1 & 0 & 1 \\
\hline opportunity to & 0 & 2 & 2 \\
\hline continue & 1 & 0 & 1 \\
\hline not contributing & 1 & 1 & 2 \\
\hline seem & 1 & 0 & 1 \\
\hline appear & 43 & 7 & 50 \\
\hline other verbs total & 64 & 6 & 70 \\
\hline still & 16 & 49 & 65 \\
\hline yet & 4 & 0 & 4 \\
\hline only & 2 & 0 & 2 \\
\hline not sufficiently & & & \\
\hline
\end{tabular}


Đorđe Dimitrijević

\begin{tabular}{|l|c|c|c|}
\hline & $\begin{array}{c}\text { With an active } \\
\text { verb }\end{array}$ & $\begin{array}{c}\text { With a passive } \\
\text { verb }\end{array}$ & In total \\
\hline potentially & 1 & 0 & 1 \\
\hline adverbs total & 87 & 55 & 142 \\
\hline needed & 39 & 0 & 39 \\
\hline pending & 12 & 0 & 12 \\
\hline crucial & 5 & 0 & 5 \\
\hline urgent & 2 & 0 & 2 \\
\hline important & 1 & 1 & 2 \\
\hline encouraged & 1 & 0 & 1 \\
\hline responsible & 1 & 0 & 1 \\
\hline insufficient & 2 & 0 & 2 \\
\hline critical & 1 & 0 & 1 \\
\hline required & 2 & 0 & 2 \\
\hline recommended & 1 & 0 & 1 \\
\hline necessary & 2 & 0 & 2 \\
\hline instrumental & 1 & 0 & 1 \\
\hline adjectives and \\
participles total & 69 & 1 & 70 \\
\hline need & 9 & 0 & 9 \\
\hline lack & 2 & 0 & 2 \\
\hline key & 1 & 0 & 1 \\
\hline an issue to be followed & 1 & 0 & 1 \\
\hline nouns total & 13 & 0 & 13 \\
\hline instead of & 2 & 0 & 2 \\
\hline due to & 397 & 240 & \\
\hline conjunctions total & & 037 \\
\hline conditionals & 1 & 0 & \\
\hline In total & 2 & 0 & 1 \\
\hline
\end{tabular}

Note: Since there are sentences with multiple modal phrases in them, the total number of modal forms is greater than the total number of analysed sentences. 


\subsection{Types of modality}

\subsubsection{Epistemic modality}

There are surprisingly few epistemic modal phrases in the report. This is probably due to the purpose of the report, which is to provide an accurate description of the situation in Serbia, which leaves no room for speculation. In fact, all the speculation in the report is connected to the future. There are no modal phrases connected to deduction in the report.

The epistemic modals in the report are modal verbs should and could and the adverb potentially. For example:

(29) This should help prioritise investigations and prosecutions. (18)

Evidentials are even fewer in number, probably for the same reason. The only evidential verbs used in the report are seem and appear, such as in:

(30) Intergovernmental agreements concluded with third countries and their implementation do not seem to be systematically in line with the principles of equal treatment, non-discrimination, transparency and competition and neither fully consistent with the relevant EU acquis and national legislation. (61)

\subsubsection{Dynamic modality}

Dynamic modals are very few in number in the report as well. There are absolutely no qualificational modals, whereas modal verbs can and could are the only ones used for volitional modality. One example is:

(31) Appeals against its decisions can be submitted to the Asylum Commission and subsequently to the Administrative Court of Appeal as a final instance. (40) 


\subsubsection{Priority modality}

The vast majority of modal phrases in the report fall under the priority modal category. This is due to the purpose of the report not only to describe the current situation, but also to give recommendations in order to improve the situation. All recommendations are by nature modal and would be categorised as priority modals.

Since in political discourse people usually talk about the good of the country, and not personal desires, bouletic modals are rare. It is, therefore, unsurprising, that there is not a single bouletic expression in the report.

Deontic and teleological modals are hard to differentiate, as there is no clear cut difference between them. "The fact that there is no clear answer to this question means that we should not think of the categories as mutually exclusive or as exhausting the range of meanings" (Portner 2009: 185). In this report, there are some modal expressions that are purely deontic, some that are purely teleological, but most of them can be described in either way. For example:

(32) Serbia needs to step up measures to protect the rights of persons facing discrimination, including LGBTI persons, persons with disabilities, persons with HIV/AIDS and other vulnerable individuals. (5)

Why does Serbia need to step up these measures? Is it the goal of the Serbian government to protect the rights of persons facing discrimination, or is it something the European Union demands of it? Or maybe both? This question cannot be answered simply by reading this report, it would be necessary to conduct a critical analysis of the government's actions regarding this area to precisely define this sentence as either deontic or teleological. Also, since fulfilling all the recommendations would grant Serbia membership in the European Union, all of them could be regarded as teleological, and membership as their goal. On the other hand, depending on the researcher's political views, they could all be regarded as demands of the European Union, in which case they would be deontic. In order 
to avoid ideological speculations, for the purposes of the present study, a simpler criterion has been established. Recommendations that include a specific reason why they are beneficial to Serbia are termed teleological, such as:

(33) Further to the adoption of the constitutional amendments, the system for the appointment and evaluation of judges and prosecutors needs to be revised to allow for fully merit-based judicial recruitments and careers. (4)

In this sentence, the specific goal is enabling fully merit-based judicial recruitments and careers. Other recommendations, which do not state a specific reason, such as (32), are termed deontic.

\subsubsection{Deontic modality}

Examples of deontic modality in the report by far outnumber examples of teleological modality. Sentences in the report containing modal verbs need to, should and must are in most cases deontic, whereas those with have to are always deontic. Here are some examples:

(34) A new media strategy was drafted in a transparent and inclusive manner; it needs to be adopted and implemented. (26) (35) Serbia furthermore should refrain from further diverging from the EU visa policy. (6)

When it comes to other verbs and verb phrases, remain and require are also mostly used as deontic, such as in:

(36) However, the Commission's recommendations made over the last few years have not been fully addressed, especially regarding de-politicisation and professionalization of public service, and therefore remain valid. (10)

Continue can be both deontic or teleological, whereas provides a good opportunity to is only used as deontic in the report.

Adverbs are almost always used as deontic. For example:

(37) According to the Ombudsman, the percentage of his recommendations followed up by the authorities remains 
high (2017: 90.6\%; 2018: 93.2\%), although certain recommendations related to "public interest" have still not been addressed. (23)

(38) The policy areas of environment and climate change have yet to receive adequate attention. (6)

There are a number of adjectives and participles that are used as deontic, and there are a number of them used as teleological. Needed is mostly used in a deontic way, such as in:

(39) Further efforts are needed to ensure systematic cooperation between the government and civil society. (9)

Pending is exclusively used as deontic. Here is one example:

(40) Full harmonisation of the law on information security with the Directive on network and information systems is pending. (66)

Crucial is almost never used as deontic. Other adjectives and participles used in a deontic way are important, encouraged, responsible, insufficient, critical, required, recommended and necessary.

Nouns have an almost equal number of deontic and teleological uses in the report. This is particularly true for the noun need. Here is one example of it being used as deontic:

(41) There is an urgent need to create space for genuine crossparty debate and conditions for meaningful participation by the opposition in the parliament. (5)

Other nouns and noun phrases used as deontic are lack, and an issue to be followed.

The conjunction instead of is used as deontic, as in (25).

\subsubsection{Teleological modality}

As stated above, there are far less examples of teleological modality than those of deontic modality in the report. Even though modal verbs were mostly used as deontic, most teleological sentences contained modal verbs need to and should with only a few examples of must. For example: 
(42) Independent regulatory bodies need to be empowered to exercise their monitoring and oversight role proactively and effectively. (7)

(43) The meeting of the parliamentary collegium in April should be followed up on with a view to improving law-making procedures. (8)

When it comes to other verbs, remain and require are almost never teleological, but the phrase would benefit from is teleological in nature, such as in:

(44) Extended confiscation is not implemented and judges and prosecutors would benefit from more training on the concept of confiscation in general and on extended confiscation in particular. (19)

As for adverbs, there is only one teleological example with yet and only a few of those with still, one of which is:

(45) The Law on public prosecution was still not amended to allow for the same transfer to the SPC. (15)

There are a few different adjectives and participles that can be used as teleological. Although mostly used as deontic, there are a few teleological examples of needed, for example:

(46) A more systematic approach towards the professional improvement and long-term training plans for judicial and prosecutorial staff as well as the councils' own staff are needed for the better overall operation of the judicial system. (15)

On the other hand, crucial is more often than not used as teleological, such as in:

(47) Such an agreement is urgent and crucial so that Serbia and Kosovo can advance on their respective European paths. (34)

Other adjectives and participles used in a teleological way are urgent, important, insufficient, necessary and instrumental.

As stated above, noun phrases are almost equally used as deontic and as teleological. There are teleological examples with need and key, one of which is: 
(48) This includes the need for a comprehensive and inclusive review of the legal framework on elections, in order to regulate all essential aspects and address gaps and loopholes. (7)

The conjunction due to is used in a teleological way, as in (26).

Table 2. Types of modality

\begin{tabular}{|l|c|c|c|c|}
\hline & epistemic & deontic & teleological & dynamic \\
\hline need to & 0 & 192 & 25 & 0 \\
\hline should & 5 & 108 & 9 & 0 \\
\hline must & 0 & 6 & 2 & 0 \\
\hline have to & 0 & 4 & 0 & 0 \\
\hline can & 0 & 0 & 0 & 6 \\
\hline could & 2 & 0 & 0 & 1 \\
\hline modal verbs total & 7 & 310 & 36 & 7 \\
\hline remain & 0 & 26 & 3 & 0 \\
\hline require & 0 & 6 & 1 & 0 \\
\hline would benefit from & 0 & 0 & 2 & 0 \\
\hline leads to uncertainty & 0 & 0 & 1 & 0 \\
\hline provides a good & 0 & 1 & 0 & 0 \\
\hline opportunity to & 0 & 1 & 1 & 0 \\
\hline continue & 0 & 0 & 1 & 0 \\
\hline not contributing & 2 & 0 & 0 & 0 \\
\hline seem & 1 & 0 & 0 & 0 \\
\hline appear & 3 & 34 & 9 & 0 \\
\hline other verbs total & 0 & 65 & 5 & 0 \\
\hline still & 0 & 64 & 1 & 0 \\
\hline yet & 0 & 4 & 0 & 0 \\
\hline only & 0 & 2 & 0 & 0 \\
\hline not sufficiently & 1 & 0 & 0 & 0 \\
\hline potentially & 0 & 32 & 7 & 0 \\
\hline adverbs total & 12 & 0 & 0 \\
\hline needed & 0 & 4 & 0 \\
\hline pending & 0 & & & \\
\hline crucial & 0 & 13 & 0 & \\
\hline
\end{tabular}


PRIORITY MODALITY IN POLITICAL WRITING...

\begin{tabular}{|l|c|c|c|c|}
\hline & epistemic & deontic & teleological & dynamic \\
\hline urgent & 0 & 0 & 2 & 0 \\
\hline important & 0 & 1 & 1 & 0 \\
\hline encouraged & 0 & 1 & 0 & 0 \\
\hline responsible & 0 & 1 & 0 & 0 \\
\hline insufficient & 0 & 1 & 1 & 0 \\
\hline critical & 0 & 1 & 0 & 0 \\
\hline required & 0 & 2 & 0 & 0 \\
\hline recommended & 0 & 1 & 0 & 0 \\
\hline necessary & 0 & 1 & 1 & 0 \\
\hline instrumental & 0 & 0 & 1 & 0 \\
\hline $\begin{array}{l}\text { adjectives and } \\
\text { participles total }\end{array}$ & 0 & 54 & 17 & 0 \\
\hline need & 0 & 5 & 4 & 0 \\
\hline lack & 0 & 2 & 0 & 0 \\
\hline key & 0 & 0 & 1 & 0 \\
\hline $\begin{array}{l}\text { an issue to be } \\
\text { followed }\end{array}$ & 0 & 1 & 0 & 0 \\
\hline nouns total & 0 & 8 & 5 & 0 \\
\hline instead of & 0 & 1 & 0 & 0 \\
\hline due to & 0 & 0 & 1 & 0 \\
\hline conjunctions total & 0 & 1 & 1 & 0 \\
\hline In total & 11 & 542 & 74 & 7 \\
\hline
\end{tabular}

\subsection{Meaning of priority modals}

All priority modal forms in the report are directives, obligatives to be precise, which should be evident from all the examples given above. As stated before, the purpose of the report is, among other things, to give recommendations to the Serbian government. All recommendations are essentially obligatives. The writer of the report does not possess the authority to give permissions to Serbia, nor can they guarantee that Serbia shall fulfil any of the recommendations given. Hence, there are no permissives or commissives in the report. 


\subsection{Subjective and objective priority modality}

The three tests proposed by Verstraete (2001) to determine the subjectivity or objectivity of a modal verb are conditionality, interrogation, and tense shift. However, tense shift is ambiguous for deontic (priority) modals, so it will not be used in the present study.

Modal verbs are deemed to have been used subjectively if they get an echoic interpretation when placed in the protasis of a conditional sentence (Verstraete 2001: 1520). For example, if (1) is put into a conditional sentence, the following is produced:

(1b) If Serbia needs to fully address all recommendations on the elections, identified by international observers, as a matter of priority...

The implication of this sentence is that it is not the opinion of the speaker that Serbia needs to address the recommendations, but someone else's. The same result is produced with a sentence containing the modal verb should, take (3) for example:

(3b) If Serbia should now provide further support to ensure the conditions are in place for it to take up operations swiftly...

If the sentence is transformed into an interrogative, the interlocutors' roles appear to be reversed. If (1) and (3) are used as examples again:

(1c) Does Serbia need to fully address all recommendations on the elections, identified by international observers, as a matter of priority?

The addressee becomes the deontic source. Similarly, with should and example (3):

(3c) Should Serbia now provide further support to ensure the conditions are in place for it to take up operations swiftly?

Since both modal verbs get an echoic interpretation in conditional sentences and change the interlocutors' roles under interrogation in other examples from the report as well, it can be safe to assume that they are used subjectively. Unfortunately, 
these tests are only valid for modal verbs and cannot be applied to sentences where the other parts of speech carry modal meaning.

\section{Conclusion}

In summary, the most common modal forms in this report are modal verbs need to and should. They are very commonly followed by a passive verb in order to hide the subject of the sentence and, thus, limit the face threatening act. In fact, face saving is quite common in political language and is often mistaken by laymen as being deliberately vague. Other frequent modal forms in the report include adverbs still and yet, verbs remain and require and various adjectives, participles, and nouns. This shows that politicians often use different forms to avoid repetitions, but also that their recommendations are not always as direct and explicit as those with modal verbs. There are very few epistemic and dynamic modals, because of the purpose of the report, which is to give recommendations, which is done by using priority modals. Deontic modals far outnumber teleological ones, without any bouletic modals, as few reasons are given why following the recommendations will benefit Serbia. All priority modals in the report are directives, specifically obligatives, as they are used by the writer to tell the Serbian government what they ought to do. Additionally, all priority modal verbs are found to be subjective, as the tests of conditionality and interrogation show speaker involvement.

When the report is examined as a whole, with its purpose of giving recommendation, it is evident that the entire text is modal by nature. In fact, political writing is in most cases modal. Politicians rarely write about the world as it is, they write about what should be done. Even in oral speeches, politicians talk about what their country ought to be.

This report attempts to present facts and recommendations objectively. However, in political writing this is often not the case. It would be beneficial for the description of political writing to conduct a similar study on a piece of writing that is not using an objective 
approach, for example a text where the opposition criticises the government. There would probably be far less concern for face saving.

Another limitation of this study is that it is tied to the concept of European integrations. In order to provide a full description of modality in political writing, further research is needed on texts from all around the world in different contexts. Hopefully, this study could provide a basis for similar research in those contexts. Describing political language would allow us to learn and teach it, allowing more people access to the political arena, which would strengthen the principles of democracy.

\section{BIBLIOGRAPHY}

Boicu 2007: R. Boicu, Modal verbs and politeness strategies in political discourse. Munich Personal RePEc Archive. Online, [https://mpra. ub.uni-muenchen.de/45913/1/MPRA_paper_45913.pdf]

European Commission 2019: European Commission, Serbia 2019 Report. Online, [https://ec.europa.eu/neighbourhood-enlargement/sites/ near/files/20190529-serbia-report.pdf]

Milkovich \& Sitarica 2017: M. Milkovich \& A. Sitarica, Epistemic modality in political discourse. Research Result. Social Studies and Humanities, 3(1), 75-79.

Orwell 1946: G. Orwell, Politics and the English language. London: Horizon. Palmer 1986: F. R. Palmer, Mood and modality. Cambridge: Cambridge University Press.

Portner 2009: P. Portner, Modality. New York: Oxford University Press.

Verstraete 2001: J. C. Verstraete, Subjective and objective modality: Interpersonal and ideational functions in the English modal auxiliary system. Journal of Pragmatics, 33(10), 1505-1528. 


\title{
Ђорђе Димитријевић
}

\section{МОДАЛНОСТ ПРИОРИТЕТА У ПОЛИТИЧКОМ ПИСАҢУ - СЛУЧАЈ ИЗВЕШТАЈА ЕВРОПСКЕ КОМИСИЈЕ О СРБИЈИ ЗА 2019. ГОДИНУ}

\begin{abstract}
Резиме
Циљ овог рада је да идентификује и анализира модалне фразе које су искоришћене у Извештају Европске комисије о Србији за 2019. годину и да те податке искористи да донесе закључке о модалности у политичком писању уопште. По прегледању извештаја, уочено је 560 фраза са модалним значењем. Најчешћи модални облици у извештају су модални глаголи need и should и прилози still и yet, али је у извештају употребљен и широк асортиман других глагола, придева, партиципа и именица са модалним значењем. Глагол који прати модални облик је често у пасиву, што потенцијално указује на говорне чинове заштите саговорниковог образа. Скоро сви модали у извештају спадају у категорију модалности приоритета, где је деонтичка модалност далеко чешћа од телеолошке, а булетичка модалност је у потпуности одсутна. Сви модали приоритета у извештају су директиви, прецизније облигативи. Коначно, применом тестова кондиционалности и интерогације, утврђено је да су сви модални глаголи приоритета у извештају субјективни. Закључак овог рада је да је овај текст, као и већина политичког писања, у суштини модалне природе.
\end{abstract}

Кључне речи: политичко писање, модалност, модалност приоритета, облигативи, субјективност. 